\title{
Nutritive value of cattle manure vermicast and its effect on in vitro ruminal gas production
}

\author{
Aminu Nasiru • Abdul Razak Alimon • \\ Norli Ismail • Mahamad Hakimi Ibrahim
}

Received: 12 September 2013/Accepted: 23 February 2014/Published online: 8 March 2014

(C) The Author(s) 2014. This article is published with open access at Springerlink.com

\begin{abstract}
Introduction The use of non-conventional feedstuffs is gaining recognition especially in developing countries. Ensiled cattle manure with other feedstuffs has been used in ruminant feeding. Vermicomposting, a tool for manure management can be employed as a means for manure treatment with the aim of enhancing nutritive value of forage. The objectives of the study were to determine the nutritive value of cattle manure vermicast (CMV) and to observe gas production in vitro due to CMV inclusion on rice straw at different proportions.

Results Vermicomposting of cattle manure at 2, 4 and 6 weeks linearly increased $(P<0.05)$ significantly crude protein and ash, while it linearly decreased $(P<0.05)$ significantly organic matter, neutral detergent fibre (NDF) and acid detergent fibre. The result showed that, gas production decline with an increased in CMV content $(P<0.05)$. CMV addition to rice straw had no significant $(P>0.05)$ effect on rumen $\mathrm{pH}$ and microbial crude protein production in vitro. CMV inclusion reduced dry matter degradability and increased partitioning factor at 48 h. $5 \%$
\end{abstract}

\author{
A. Nasiru $(\bowtie) \cdot$ N. Ismail · M. H. Ibrahim \\ Environmental Technology Division, School of Industrial \\ Technology, Universiti Sains Malaysia (USM), \\ 11800 Pulau Pinang, Malaysia \\ e-mail: nasirua4601@buk.edu.ng \\ N. Ismail \\ e-mail: norlii@usm.my \\ M. H. Ibrahim \\ e-mail: mhakimi@usm.my
}

\section{A. R. Alimon}

Department of Animal Science, Faculty of Agriculture, Universiti Putra Malaysia (UPM), Serdang, Malaysia

e-mail: ralimon@agri.upm.edu.my inclusion level of CMV gave the highest results while $30 \% \mathrm{CMV}$ had the least results.

Conclusion Vermicomposting of cattle manure increased its nutritive value, with increase in crude protein content and decrease in NDF and ADF. Results of in vitro gas production and rumen fermentation profiles from this study indicated that inclusion of CMV reduced gas production and DMD; however, it increased $\mathrm{PF}_{48}$, with no significant changes in MCP. Vermicomposting has the potential of being used as another tool for forage treatment and addition of CMV could be expected to reduce ruminant gas production, increase ME and microbial protein synthesis.

Keywords Cattle manure vermicast - Gas production . Partition factor $\cdot$ Rice straw

\section{Introduction}

Inadequate supply of good-quality feed is the main factor hindering the progress of animal production in many developing countries, especially during dry season. This has necessitated the use of non-conventional feed resources in order to meet livestock requirement for nutrients and enhance their performance. Anything that is been excreted by ruminants is considered to be non-digestible; however, there are significantly high amounts of soluble materials in the manure and these can be utilised by ruminants (MooYoung and Chahal 1979). The use of cattle manure as ruminants feed will reduce feeding cost as well as animal waste pollution, and it will also provide nutrients to the animals (Martínez-Avalos et al. 1998; Sarwar et al. 2011). Different processing methods had been used in processing cattle manure as feedstuff but, the most commonly used is 
ensiling methods (Sarwar et al. 2006). Cattle manure was ensiled at different proportions up to $50 \%$ inclusion with different agro-by-products. Cattle manure was ensiled with cane molasses-urea mixture-treated wheat straw (Sarwar et al. 2006, 2011); it was also ensiled with cane molassesurea mixture and corn stover (Martínez-Avalos et al. 1998) and the same mixture without urea (Cobos et al. 1997). It was also ensiled with bakery by-products and tallow (Bórquez et al. 2010). These were fed to buffalos, cattle and small ruminants. The results showed an increase in dry matter, organic matter, crude protein and NDF intake; however, there were no significant differences in nutrients' apparent digestibilities.

Vermicomposting is a mesophilic bio-oxidative process of organic materials that involves the joint action of earthworm and micro-organism. This method has been employed in ruminant manure management (Garg et al. 2006; Velasco-Velasco et al. 2011). In addition to providing eco-friendly and cost-effective organic and biofertiliser, cattle manure vermicast (CMV) has the potential of being fed as supplement to small ruminants. During vermicomposting carbon nitrogen $(\mathrm{C}: \mathrm{N})$ ratio decreases as vermicomposting reaches maturity and stability, thereby increasing the crude protein content of vermicast. It has also been observed that, vermicomposting process reduces phenolic content of the biomass. Cellulolytic microbial activities were reported during vermicomposting, this will reduce the fibre content of the manure and possibly increase the non-structural carbohydrate content (Benítez et al. 2002; Masciandaro et al. 2010; Romero et al. 2006). These properties have the potential of increasing the nutritive value of vermicast from cattle manure. In vitro rumen fermentation technique has been used for evaluation of nutritional value of feedstuffs, as there is empirical relationship between in vitro gas production and rumen degradation (Makar 2004).

The objectives of this study were to evaluate the effect of CMV harvesting time on nutrients composition of the cast and to assess the in vitro gas production of inclusion of $\mathrm{CMV}$ at different proportion to rice straw.

\section{Materials and methods}

Vermicomposting of cattle manure

Cattle manure was collected from selected farm in Kepala Batas, Penang, Malaysia. The manure was air dried before use. The earthworms, African nightcrawlers (Eudrilus eugeniae) were obtained from BP Gemilang Agrobio, Balik Pulau, Penang. The experiment was performed in a plastic container measuring $0.31 \mathrm{~m} \times 0.24 \mathrm{~m} \times 0.09 \mathrm{~m}$ (length $\times$ width $\times$ depth). $0.5 \mathrm{~kg}$ of cattle manure was placed into
Table 1 Chemical composition of rice straw and cattle manure vermicast $\left(\mathrm{g} \mathrm{kg}^{-1} \mathrm{dm}\right)$

\begin{tabular}{lllll}
\hline & OM & CP & NDF & ADF \\
\hline Cattle manure vermicast & 861.8 & 92.4 & 589 & 314.9 \\
Rice straw & 875.5 & 34.6 & 675.1 & 461 \\
\hline
\end{tabular}

$O M$ organic matter, $C P$ crude protein, $N D F$ neutral detergent fibre, $A D F$ acid detergent fibre

the container and the moisture content was adjusted between 70 and $80 \%$ by spraying adequate quantities of distilled water periodically (every 3 days) during the study period, as described by Garg et al. (2006). After pretreatment, 15 adult earthworms were introduced into the container, replicated six times. The experiment was conducted at Vermitech Laboratory of Environmental Technology Division, School of Industrial Technology, Universiti Sains Malaysia, Malaysia. The daily temperature fluctuated between 25 and $33{ }^{\circ} \mathrm{C}$; it lasted for 8 weeks. Vermicast were harvested at 2, 4 and 6 weeks. Vermicast was stored at $4{ }^{\circ} \mathrm{C}$ before further analysis.

\section{Chemical analyses}

Samples of vermicast harvested and rice straw were analysed for proximate analysis. Dry matter (DM) was determined at $105{ }^{\circ} \mathrm{C}$ for $24 \mathrm{~h}$. Ash content was determined by placing sample in a furnace at $550{ }^{\circ} \mathrm{C}$ for $4 \mathrm{~h}$, and organic matter (OM) was calculated as weight lost during placement of sample for ash determination. Crude protein (CP) was determined according to Kjeldahl method using 2400 Kjeltec analyser unit (Foss tecator) according to AOAC (1997). The neutral detergent fibre (NDF) and acid detergent fibre (ADF) was analysed according to Van Soest et al. (1991).

\section{Sample preparation}

Rice straw was collected from Ruminant research unit of Department of Animal Science at Universiti Putra Malaysia, together with CMV harvested at 6 week were oven dried at $60{ }^{\circ} \mathrm{C}$ for $48 \mathrm{~h}$ and milled to pass $1 \mathrm{~mm}$ sieve. CMV was added to rice straw at an inclusion rate of 0,5 , 10, 15, 20, 2530 and $100 \%$. The chemical composition is shown in Table 1.

\section{In vitro gas production}

The experiment was conducted in the Department of Animal Science, Universiti Putra Malaysia. Gas production was determined as described by Menke and Steingass (1988). Samples of CMV supplemented with rice straw 
(200 mg) were weighed into $100 \mathrm{ml}$ calibrated glass syringes with pistons lubricated with Vaseline. Buffered mineral solution (Menke and Steingass 1988) was prepared and placed in a water bath at $39{ }^{\circ} \mathrm{C}$ under continuous flushing with $\mathrm{CO}_{2}$. Rumen fluid was collected before morning feeding from two ruminally fistulated kajang goats, that were fed concentrate as a supplement and rice straw ad libitum twice daily at 0730 and 1700 hours. Rumen fluid was pumped from the rumen with a manually operated vacuum pump and transferred into two prewarmed thermos flasks, transported to the laboratory, combined, filtered through eight layers of cheesecloth and flushed with $\mathrm{CO}_{2}$. Rumen fluid was added to the buffered mineral solution with constant stirring, while maintained in a water bath at $39^{\circ} \mathrm{C}$. About $30 \mathrm{ml}$ of buffered rumen fluid was added into syringes containing the samples. Air bubble was removed, clip was closed, the initial volume was recorded and the syringe placed in a water bath at $39{ }^{\circ} \mathrm{C}$. Treatments were incubated in triplicates and two runs were carried out. Gas production was recorded at 2, 4, 6, 12, 24 and $48 \mathrm{~h}$. At the end of incubation period ( $48 \mathrm{~h}), \mathrm{pH}$ was measured.

In vitro dry matter degradability (DMD)

This was determined by the procedure of Elghandour et al. (2013). At the end of the incubation period, the contents of each syringe were poured into crucible. Fermentation residues were dried at $105{ }^{\circ} \mathrm{C}$ overnight to estimate DM disappearance with loss in weight after drying being the measure of undegradable DM.

\section{Calculations}

Metabolizable energy ( $\mathrm{ME}, \mathrm{MJ} \mathrm{kg}^{-1} \mathrm{DM}$ ) and in vitro organic matter degradability (OMD, $\mathrm{g} \mathrm{kg}^{-1}$ organic matter) were estimated according to Elghandour et al. (2013) and Salem et al. (2013) as:

$$
\begin{aligned}
\mathrm{ME}= & 2.20+0.136 \mathrm{GP}\left(\mathrm{ml} 0.5 \mathrm{~g}^{-1} \mathrm{DM}\right)+0.057 \mathrm{CP}(\% \mathrm{DM}) \\
\mathrm{OMD}= & 148.8+8.89 \mathrm{GP}+4.5 \mathrm{CP}\left(\mathrm{g} \mathrm{kg}^{-1} \mathrm{DM}\right) \\
& +0.651 \mathrm{Ash}\left(\mathrm{g} \mathrm{kg}^{-1} \mathrm{DM}\right)
\end{aligned}
$$

where GP is net gas production in $\mathrm{ml}$ from $200 \mathrm{mg}$ of dry sample after $24 \mathrm{~h}$ of incubation.

The partitioning factor at $48 \mathrm{~h}$ of incubation $\left(\mathrm{PF}_{48}\right.$; $\mathrm{a}$ measure of fermentation efficiency) was calculated as the ratio of in vitro dry matter degradability (DMD, $\mathrm{mg}$ ) to the volume of gas $(\mathrm{ml})$ produced at $48 \mathrm{~h}$ according to Blümmel et al. (1997).

Microbial crude protein production (MCP) was calculated according to Blümmel et al. (1997) as:
Table 2 Chemical composition of cattle manure and its vermicast $\left(\mathrm{g} \mathrm{kg}^{-1} \mathrm{DM}\right)$

\begin{tabular}{lrrrrr}
\hline & \multicolumn{6}{l}{ Treatments } \\
\cline { 2 - 6 } & Manure & \multicolumn{1}{c}{$A$} & \multicolumn{1}{l}{$B$} & \multicolumn{1}{l}{$C$} & SE \\
\hline Dry matter & $401.3^{\mathrm{a}}$ & $126.4^{\mathrm{c}}$ & $133.1^{\mathrm{bc}}$ & $147.5^{\mathrm{b}}$ & 0.72 \\
Organic matter & $881.6^{\mathrm{a}}$ & $887.9^{\mathrm{b}}$ & $867.7^{\mathrm{c}}$ & $861.8^{\mathrm{d}}$ & 0.24 \\
Crude protein & $58.6^{\mathrm{d}}$ & $67.1^{\mathrm{c}}$ & $79.2^{\mathrm{b}}$ & $92.4^{\mathrm{a}}$ & 0.35 \\
NDF & $646.9^{\mathrm{a}}$ & $631.4^{\mathrm{b}}$ & $611.4^{\mathrm{c}}$ & $589.0^{\mathrm{d}}$ & 0.65 \\
ADF & $401.8^{\mathrm{a}}$ & $376.4^{\mathrm{b}}$ & $365.8^{\mathrm{b}}$ & $314.9^{\mathrm{c}}$ & 0.69 \\
Ash & $118.4^{\mathrm{d}}$ & $112.1^{\mathrm{c}}$ & $132.3^{\mathrm{b}}$ & $138.2^{\mathrm{a}}$ & 0.24 \\
\hline
\end{tabular}

Different superscript in the same row is significantly different $(P<0.05)$

$A$ vermicast harvested at 2 weeks, $B$ vermicast harvested at 4 weeks, $C$ vermicast harvested at 6 weeks

$N D F$ neutral detergent fibre, $A D F$ acid detergent fibre, $S E$ standard error

$\operatorname{MCP}\left(\mathrm{mg} \mathrm{g}^{-1} \mathrm{DM}\right)=\mathrm{mg} \mathrm{DMD}-\left(\mathrm{ml}\right.$ gas $\left.\times 2.2 \mathrm{mgml}^{-1}\right)$

where $2.2 \mathrm{mg} \mathrm{ml}^{-1}$ is a stoichiometric factor which expresses $\mathrm{mg}$ of $\mathrm{C}, \mathrm{H}$ and $\mathrm{O}$ required for the SCFA gas associated with production of $1 \mathrm{ml}$ of gas.

Statistical analyses

Data generated on effect of CMV harvesting time, in vitro ruminal gas production and fermentation parameters were analysed for analysis of variance (ANOVA), using General linear model procedure of (SAS 2009). Means were separated using least significant difference (LSD) at $5 \%$.

\section{Results and discussion}

\section{Nutritive value of CMV}

The effect of harvesting time of CMV on its nutrients composition is presented in Table 2. OM, NDF and ADF decreased $(P<0.05)$ with increase in number of weeks of harvesting. OM decreased from 88.16 to $86.18 \%$, while NDF decreased from 64.69 to $58.90 \%$, and ADF decreased from 40.18 to $31.49 \%$, over the 6-week treatment period. On the other hand, there were increases $(P<0.05)$ in $\mathrm{CP}$ and ash contents with increase in number of weeks of harvesting. The increases were from 5.86 to $9.24 \%$ for $\mathrm{CP}$ and 11.84 to $13.82 \%$ for Ash, over the period of 6 weeks treatment. The decrease in OM was due to earthworm's activities and microbial fermentation, while increase in ash was reflection of OM loss, this agrees with Cobos et al. (1997). The decrease in NDF and ADF value may be due to the solubilisation of fibre contents as a result of cellulolytic 
Table 3 In vitro cumulative gas production $\left(\mathrm{ml} \mathrm{g}^{-1} \mathrm{DM}\right)$ at various incubation times of rice straw supplemented with cattle manure vermicast at different proportions

\begin{tabular}{|c|c|c|c|c|c|c|c|c|c|}
\hline \multirow[t]{2}{*}{ A } & \multicolumn{8}{|c|}{ Treatments } & \multirow[t]{2}{*}{ SE } \\
\hline & $5 \% \mathrm{VC}$ & $10 \% \mathrm{VC}$ & $15 \% \mathrm{VC}$ & $20 \% \mathrm{VC}$ & $25 \% \mathrm{VC}$ & $30 \% \mathrm{VC}$ & $\mathrm{VC}$ & $\mathrm{RS}$ & \\
\hline GP2 & $10.0^{\mathrm{a}}$ & $5.83^{\mathrm{ab}}$ & $4.17^{b}$ & $5.83^{\mathrm{ab}}$ & $5.00^{\mathrm{ab}}$ & $5.00^{\mathrm{ab}}$ & $6.67^{\mathrm{ab}}$ & $6.67^{\mathrm{ab}}$ & 2.68 \\
\hline GP4 & $22.50^{\mathrm{a}}$ & $9.17^{\mathrm{b}}$ & $5.83^{b}$ & $10.83^{\mathrm{b}}$ & $7.50^{\mathrm{b}}$ & $8.30^{\mathrm{b}}$ & $8.33^{\mathrm{b}}$ & $12.55^{\mathrm{ab}}$ & 5.24 \\
\hline GP6 & $26.67^{\mathrm{a}}$ & $10.83^{\mathrm{b}}$ & $8.33^{\mathrm{b}}$ & $14.17^{\mathrm{ab}}$ & $16.67^{\mathrm{ab}}$ & $10.83^{\mathrm{b}}$ & $10.00^{\mathrm{b}}$ & $15.00^{\mathrm{ab}}$ & 6.21 \\
\hline GP12 & $35.00^{\mathrm{a}}$ & $20.00^{\mathrm{b}}$ & $18.33^{\mathrm{b}}$ & $22.50^{\mathrm{ab}}$ & $22.50^{\mathrm{ab}}$ & $25.00^{\mathrm{ab}}$ & $16.67^{\mathrm{b}}$ & $22.50^{\mathrm{ab}}$ & 6.44 \\
\hline GP24 & $64.17^{\mathrm{a}}$ & $47.50^{\mathrm{ab}}$ & $52.50^{\mathrm{ab}}$ & $51.67^{\mathrm{ab}}$ & $50.83^{\mathrm{ab}}$ & $39.17^{\mathrm{bc}}$ & $30.83^{\mathrm{c}}$ & $42.52^{\mathrm{bc}}$ & 7.92 \\
\hline GP48 & $175.00^{\mathrm{a}}$ & $154.17^{\mathrm{ab}}$ & $150.83^{\mathrm{ab}}$ & $137.50^{\mathrm{bc}}$ & $120.83^{c}$ & $118.33^{\mathrm{c}}$ & $54.17^{\mathrm{d}}$ & $147.50^{\mathrm{bc}}$ & 15.35 \\
\hline
\end{tabular}

Different superscript in the same row is significantly different $(P<0.05)$

$A$ mean of the cumulative gas volume at time of 2, 4, 6, 12, 24 and $48 \mathrm{~h}$ incubation

$V C$ cattle manure vermicast, $R S$ rice straw

Table 4 In vitro fermentation profile as influenced by cattle manure vermicast inclusion at different proportions

\begin{tabular}{|c|c|c|c|c|c|c|c|c|c|}
\hline \multirow[t]{2}{*}{ B } & \multicolumn{8}{|c|}{ Treatments } & \multirow[t]{2}{*}{ SE } \\
\hline & $5 \% \mathrm{VC}$ & $10 \% \mathrm{VC}$ & $15 \% \mathrm{VC}$ & $20 \% \mathrm{VC}$ & $25 \% \mathrm{VC}$ & $30 \% \mathrm{VC}$ & $\mathrm{VC}$ & $\mathrm{RS}$ & \\
\hline $\mathrm{pH}$ & $6.73^{\mathrm{a}}$ & $6.67^{\mathrm{a}}$ & $6.80^{\mathrm{a}}$ & $6.77^{\mathrm{a}}$ & $6.73^{\mathrm{a}}$ & $6.80^{\mathrm{a}}$ & $6.70^{\mathrm{a}}$ & $6.80^{\mathrm{a}}$ & 0.08 \\
\hline $\mathrm{ME}$ & $8.94^{\mathrm{ab}}$ & $7.96^{\mathrm{bc}}$ & $8.45^{\mathrm{b}}$ & $8.54^{\mathrm{b}}$ & $8.64^{\mathrm{ab}}$ & $7.99^{\mathrm{bc}}$ & $9.56^{\mathrm{a}}$ & $7.31^{\mathrm{c}}$ & 0.54 \\
\hline DMD & $546.3^{\mathrm{a}}$ & $525.5^{\mathrm{ab}}$ & $519.2^{\mathrm{ab}}$ & $505.8^{\mathrm{ab}}$ & $469.3^{\mathrm{ab}}$ & $354.1^{\mathrm{c}}$ & $428.0^{\mathrm{b}}$ & $568.1^{\mathrm{a}}$ & 31.59 \\
\hline OMD & $53.18^{\mathrm{b}}$ & $49.67^{\mathrm{b}}$ & $51.61^{\mathrm{b}}$ & $51.68^{\mathrm{b}}$ & $49.32^{\mathrm{b}}$ & $37.16^{\mathrm{c}}$ & $61.14^{\mathrm{a}}$ & $49.35^{\mathrm{b}}$ & 5.42 \\
\hline $\mathrm{PF}_{48}$ & $3.15^{\mathrm{b}}$ & $3.41^{\mathrm{b}}$ & $3.46^{\mathrm{b}}$ & $3.76^{\mathrm{b}}$ & $3.99^{\mathrm{b}}$ & $2.96^{\mathrm{b}}$ & $7.06^{\mathrm{a}}$ & $3.99^{\mathrm{b}}$ & 0.47 \\
\hline $\mathrm{MCP}$ & $469.3^{\mathrm{a}}$ & $457.7^{\mathrm{a}}$ & $452.8^{\mathrm{a}}$ & $449.3^{\mathrm{a}}$ & $416.1^{\mathrm{a}}$ & $419.5^{\mathrm{a}}$ & $404.2^{\mathrm{b}}$ & $454.7^{\mathrm{a}}$ & 28.28 \\
\hline
\end{tabular}

Different superscript in the same row is significantly different $(P<0.05)$

$B$ in vitro fermentation profiles; $\mathrm{pH}$, ruminal $\mathrm{pH}$; $\mathrm{DMD}$, dry matter degradability $\left(\mathrm{mg} \mathrm{g}^{-1} \mathrm{DM}\right)$; ME, metabolizable energy (MJ kg $\left.{ }^{-1} \mathrm{DM}\right)$; $\mathrm{OMD}$, in vitro organic matter degradability $\left(\mathrm{g} \mathrm{kg}^{-1} \mathrm{MS}\right) ; \mathrm{PF}_{48}$, partitioning factor ( $\mathrm{mg} \mathrm{DMD} / \mathrm{ml}$ gas); MCP, microbial crude protein production $\left(\mathrm{mg} \mathrm{g}^{-1} \mathrm{DM}\right)$

$V C$ cattle manure vermicast, $R S$ : rice straw

microbial activities, as Benítez et al. (2002) reported cellulolytic activity during vermicomposting. While an increase in $\mathrm{CP}$ content might be due to loss of carbon during vermicomposting and nitrogen excrement from the earthworms, as this increases the CP content (Singh et al. 2011; Garg et al. 2006), microbial biomass may also increase the CP value of CMV. The nutritive values obtained from CMV were within the ranges reported for silage of cattle manure mixed with other feedstuffs (Bórquez et al. 2010).

In vitro gas production

Increasing CMV proportions decreased $(P<0.05)$ net gas production at $48 \mathrm{~h}$ (Table 3 ). Table 4 shows the in vitro fermentation profile as influence by cattle manure vermicast inclusion at different proportions. Inclusion of CMV has no significant effect $(P>0.05)$ on ruminal $\mathrm{pH}$ in vitro. Compared with the treatments, rice straw inclusive, CMV has significantly $(P<0.05)$ higher ME compared with rice straw, inclusion of CMV increased ME. Addition of CMV decreased in vitro rumen degradability significantly $(P<0.05)$. Except with CMV, there was no significant $(P>0.05)$ difference among treatments due to addition of $\mathrm{CMV}$ on $\mathrm{PF}_{48}$. Inclusion of $\mathrm{CMV}$ reduces $\mathrm{PF}_{48}$, however, the value increased with an increase of CMV addition. The same trend was observed with MCP. Generally $5 \%$ level of CMV had the highest results, while $30 \% \mathrm{CMV}$ inclusion level had the least compared with other treatments. However, comparing sole rice straw and sole CMV, except for $\mathrm{ME}$ and $\mathrm{PF}_{48}$ rice straw has the high value.

The $\mathrm{pH}$ values obtained were within the range for small ruminant as reported by Yáñez Ruiz et al. (2004) and Salem et al. (2013). The decrease in gas production corresponds to increase in CMV proportion. The decrease in gas production observed may be due to dryness of the samples used as Calabrò et al. (2005b) reported that dried samples had lower gas volume production compared to fresh silage. Another possible reason for decrease in gas production with increase in CMV content might be vermicomposting, as Calabrò 
et al. (2005a) reported that preservation such as ensiling reduces gas yield of the neutral detergent-soluble fractions. This may be applicable to vermicomposting. Decrease in microbial activity may be responsible for decrease in gas production with increase in CMV content and this may be due to humification of the cattle manure vermicast. Microbial activity decreases with an increase in cell wall content with advancing plant maturity (Guglielmelli et al. 2011), with regard to vermicomposting humification increases with maturity and stability of the vermicompost. The ME values obtained were within the range of ME value for forages reported by Menke and Steingass (1988). The high ME value of CMV may be due to its lower NDF value, this may increase the energy value of the cast. Dehghani et al. (2012) reported that reduction in NDF concentration might increase the energy value. The decrease in DMD was due to the effect of CMC inclusion, this might be due to polymerisation of the vermicast as a result of microbial activities, after which other micro-organisms find it difficult to act upon. This may likely apply to rumen microbes. Bernal et al. (2009) reported that in composting decomposition particle may coat the surface with an impenetrable humified layer, therefore, making it difficult for microorganisms to access it. Moreover, vermicomposting as a form of preservation may contribute to lower DMD due to increase of CMV inclusion. According to Calabrò et al. (2005a) ensiling reduces organic matter degradability, lower net energy content and reduces the digestion rate; this may be applicable to vermicomposting. The $\mathrm{PF}_{48}$ values reported in this study were within the theoretical range (2.74-4.41) reported by Makar (2004) except for CMV. According to Makar (2004), high PF value is directly associated high efficiency of microbial protein synthesis, meaning more of degraded matter is incorporated into microbial biomass. The high $\mathrm{PF}_{48}$ value reported for $\mathrm{CMV}$ in this study might be due to humified nature of the cast, as it was reported that tannin-rich samples have higher PF.

\section{Conclusion}

Vermicomposting of cattle manure increased its nutritive value, with increase in crude protein content and decrease in NDF and ADF. Based on this result therefore, vermicomposting has the potential of being used as another tool for forage treatment. Results of in vitro gas production and rumen fermentation profiles from this study indicated that inclusion of CMV reduced gas production and DMD, however, increased $\mathrm{PF}_{48}$ with no significant changes in MCP. Therefore, CMV addition could be expected to reduce ruminant gas production, increase $\mathrm{ME}$ and microbial protein synthesis.
In order to determine the suitability of using cattle manure vermicast as a feed for small ruminant finishing product of standard quality, more experiments are needed to assess the intake, digestibility, blood chemistry and haematological counts as well effect of CMV on carcass quality.

Authors' contributions MHI and NI conceived the study and helped in drafting the manuscript. ARA designed and co-ordinated the experimental study. AN collected and analysed the data, and drafted the manuscript. MHI, NI and ARA helped in the interpretation of the data, provided guidance and improved the quality of the manuscript. All authors read and approved the final manuscript

Acknowledgments The study was funded through Universiti Sains Malaysia (USM) grant (Grant No: 304/PTEKIND/6730067). The authors acknowledge Department of Animal Science, Universiti Putra Malaysia (UPM), for providing research facilities. A. Nasiru acknowledges USM-TWAS PG fellowship 2010 for fellowship award.

Open Access This article is distributed under the terms of the Creative Commons Attribution License which permits any use, distribution, and reproduction in any medium, provided the original author(s) and the source are credited.

\section{References}

Benítez E, Sainz H, Melgar R, Nogales R (2002) Vermicomposting of a lignocellulosic waste from olive oil industry: a pilot scale study. Waste Manag Res 20(2):134-142. doi:10.1177/073424 2x0202000205

Bernal MP, Alburquerque JA, Moral R (2009) Composting of animal manures and chemical criteria for compost maturity assessment. A review. Biores Technol 100(22):5444-5453. doi:10.1016/j. biortech.2008.11.027

Blümmel M, Steinga $\beta$ H, Becker K (1997) The relationship between in vitro gas production, in vitro microbial biomass yield and $\mathrm{N}$ incorporation and its implications for the prediction of voluntary feed intake of roughages. Br J Nutr 77(06):911-921. doi:10. 1079/BJN19970089

Bórquez JL, Pinos-Rodríguez JM, González SS, Domínguez I, Bárcena R, Mendoza G, Cobos M (2010) Use of different kind of silage dairy cattle manure in lamb nutrition. Ital J Anim Sci 9(1)

Calabrò S, Cutrignelli MI, Bovera F, Piccolo G, Infascelli F (2005a) In vitro fermentation kinetics of carbohydrate fractions of fresh forage, silage and hay of Avena sativa. J Sci Food Agric 85(11):1838-1844. doi:10.1002/jsfa.2186

Calabrò S, Cutrignelli MI, Piccolo G, Bovera F, Zicarelli F, Gazaneo MP, Infascelli F (2005b) In vitro fermentation kinetics of fresh and dried silage. Anim Feed Sci Technol 123-124(Part 1): 129-137. doi:10.1016/j.anifeedsci.2005.04.047

Cobos PM, González SM, Mendoza GDM, García CB, Barcena RG (1997) Nutritional evaluation of cattle manure, molasses and corn stover silage for lambs. Small Rumin Res 25(1):33-38. doi: 10.1016/S0921-4488(96)00966-2

Dehghani MR, Weisbjerg MR, Hvelplund T, Kristensen NB (2012) Effect of enzyme addition to forage at ensiling on silage 
chemical composition and NDF degradation characteristics. Livest Sci 150(1-3):51-58. doi:10.1016/j.livsci.2012.07.031

Elghandour MMY, Salem AZM, Gonzalez-Ronquillo M, Bórquez JL, Gado HM, Odongo NE, Peñuelas CG (2013) Effects of exogenous enzymes on in vitro gas production kinetics and ruminal fermentation of four fibrous feeds. Anim Feed Sci Technol 179(1):46-53

Garg VK, Yadav YK, Sheoran A, Chand S, Kaushik P (2006) Livestock excreta management through vermicomposting using an epigeic earthworm Eisenia fetida. Environmentalist 26(4):269-276. doi:10.1007/s10669-006-8641-z

Guglielmelli A, Calabro S, Primi R, Carone F, Cutrignelli MI, Tudisco R, Piccolo G, Ronchi B, Danieli PP (2011) In vitro fermentation patterns and methane production of sainfoin (Onobrychis viciifolia Scop.) hay with different condensed tannin contents. Grass Forage Sci 66(4):488-500. doi:10.1111/ j.1365-2494.2011.00805.x

Makkar HPS (2004) Recent advances in the in vitro gas method for evaluation of nutritional quality of feed resources. In: Health FAPa (ed) Assessing quality and safety of animal feeds, vol 160. Food and Agriculture Organisation of the United Nations, Rome, pp 55-88

Martínez-Avalos AMM, Mendoza GD, Cobos MA, González S, García-Bojalil CM, Bárcena R (1998) Nutritional evaluation of cattle manure silage with molasses for ruminants. Anim Feed Sci Technol 70(3):257-264. doi:10.1016/s0377-8401(97)00007-2

Masciandaro G, Macci C, Doni S, Ceccanti B (2010) Use of earthworms (Eisenia fetida) to reduce phytotoxicity and promote humification of pre-composted olive oil mill wastewater. J Sci Food Agric 90(11):1879-1885. doi:10.1002/jsfa.4028

Menke KH, Steingass H (1988) Estimation of the energetic feed value obtained from chemical analysis and in vitro gas production using rumen fluid. Anim Res Dev 28(1):7-55

Moo-Young M, Chahal DS (1979) Utilization of cattle manure for single-cell protein production with Chaetomium cellulolyticum. Anim Feed Sci Technol 4(3):199-208. doi:10.1016/03778401(79)90013-0
Romero E, Salido A, Cifuentes C, Fernández J-D, Nogales R (2006) Effect of vermicomposting process on pesticide sorption capability using agro-industrial wastes. Int J Environ Anal Chem 86(3-4):289-297. doi:10.1080/03067310500249906

Salem AZM, C-s Zhou, Z-1 Tan, Mellado M, Salazar MC, Elghandopur MMMY, Odongo NE (2013) In vitro ruminal gas production kinetics of four fodder trees ensiled with or without molasses and urea. J Integr Agricul 12(7):1234-1242. doi:10. 1016/S2095-3119(13)60438-4

Sarwar M, Nisa M, Hassan Z, Shahzad MA (2006) Influence of urea molasses treated wheat straw fermented with cattle manure on chemical composition and feeding value for growing buffalo calves. Livest Sci 105(1-3):151-161. doi:10.1016/j.livsci.2006. 05.021

Sarwar M, Shahzad M, Nisa M, Afzal D, Sharif M, Saddiqi H (2011) Feeding value of urea molasses-treated wheat straw ensiled with fresh cattle manure for growing crossbred cattle calves. Trop Anim Health Prod 43(3):543-548. doi:10.1007/s11250-0109745-5

SAS (2009) In: User's Guide: Statistics, Version 9.2, 2nd edn. SAS Institute, Inc., Cary, NC, USA

Singh RP, Embrandiri A, Ibrahim MH, Esa N (2011) Management of biomass residues generated from palm oil mill: vermicomposting a sustainable option. Resour Conserv Recycl 55(4):423-434. doi:10.1016/j.resconrec.2010.11.005

Van Soest PJ, Robertson J, Lewis B (1991) Methods for dietary fiber, neutral detergent fiber, and nonstarch polysaccharides in relation to animal nutrition. J Dairy Sci 74(10):3583-3597

Velasco-Velasco J, Parkinson R, Kuri V (2011) Ammonia emissions during vermicomposting of sheep manure. Bioresour Technol 102(23):10959-10964. doi:10.1016/j.biortech.2011.09.047

Yáñez Ruiz DR, García AIM, Moumen A, Alcaide EM (2004) Ruminal fermentation and degradation patterns, protozoa population and urinary purine derivatives excretion in goats and wethers fed diets based on olive leaves. J Anim Sci 82(10): 3006-3014 